\title{
Composition of the Food of Roe Deer Living in Fields and the Effects of their Feeding on Plant Production ${ }^{1}$
}

\author{
Jan KAŁUZIŃSKI
}

\begin{abstract}
Kałuziński J., 1982: Composition of the food of roe deer living in fields and the effects of their feeding on plant production. Acta theriol., 27, 31: 457-470 [With 1 Table \& Figs.]

A botanical analysis was made of food contents taken from the rumen of 125 roe deer Capreolus capreolus (Linnaeus, 1758), obtained during the hunting season in an experimental field area. The roe deer's food over the annual cycle is formed by 85 plant species, but six species of cultivated plants are of basic importance. On an average over the course of a year the proportion of these six plants in food biomass is approximately $66 \%$, being highest in summer (approx. 97\%) and winter (approx. 74\%). The plant most intensively consumed by roe deer is rye ( $22 \%$ of food consumed). Frequency of occurrence of different plant in the roe deer's food is directly connected with the season of the year. It was calculated that the whole population inhabiting an area of 15,000 ha by its consumption reduces the biomass supply of basic cultivated plants (rye, rape and lucerne) during the vegetation resting period of plants by $1 \%$.
\end{abstract}

[Polish Hunting Association, Research Station, 62-055 Czempiń, Poland]

\section{INTRODUCTION}

The occurrence of roe deer in large numbers in some regions of Poland, in the shaped and intensively cultivated environment formed by cultivated fields (Kałuziński, 1974), may constitute an important ecological problem (Kałuziński \& Bresiński, 1976). The roe deer as a constant component of agrocenoses must, depending on population density, exert a certain influence on cultivated plants, and therefore studies on the composition of the roe deer's food depending on the habitat conditions under which they live, and on population density, may also be of practical importance, in addition to increasing our knowledge. There are two main problems of particular importance here: the effect of these mammals on the habitat, and especially on the biomass of cultivated plants, and the significance of roe deer as an object of game management. In this connection a source of conflict may arise, such as that present in a forest habitat (Dzięciołowski, 1971; Fruziński et al., 1978).

The purpose of the present study was to ascertain the composition

1 Praca wykonana w ramach problemu MR-II/15 koordynowanego przez Instytut Ekologii PAN. 
of the roe deer's food under agrocenosis conditions, by means of analysis of the rumen contents. Attention was given to the seasonal preferences for different components of their diet and consumption of food resources by the roe deer population was defined, particularly in relation to the vegetation resting period of plants. Comparison was also made of the composition of the roe deer's diet in forest and field ecosystems.

\section{METHODS AND MATERIAL}

The studies were carried out in an experimental field area of the Polish Hunting Association at Czempiń, situated in the western part of Poland. The area, 15,000 ha in extent $(13,500$ ha of which is suitable for breeding roe deer) is a typical agricultural landscape in which large-scale field farming predominates about $70 \%$ of the area (Kałuziński \& Pielowski, 1976). This range is numerously inhabited by two herbivorous mammals: (1) the hare Lepus capensis (Linnaeus, 1758) and (2) the roe deer Capreolus capreolus (Linnaeus, 1758) (Pielowski, 1975; Kałuziński, 1982a). Other details describing the area are to be found in the study by Kałuziński (1982a).

Two methods are mainly used to determine the composition of the roe deer's diet: (1) botanical analysis of stomach contents and (2) direct observations of feeding animals or recording traces left by feeding, termed "contacts". The first method was used by, inter alia, Siuda, Zurowski \& Siuda, 1969; Knorr \& Briedermann, 1976; Gębczyńska, 1980; Jackson, 1980; Cederlund et al., 1980 and others. The second method for ascertaining the diet of roe deer, or modification of this method, has been used by Bobek, Weiner \& Zieliński, 1972; Szmidt, 1975; Borowski \& Kossak, 1975; Kossak, 1980, while Helle (1980) defined by microscopic examination the proportions of different plants in samples of excrements. $\mathrm{He}$ supplemented the data obtained by direct observations in the animals' feeding places.

All these methods are burdened by greater or lesser errors. A considerable part of the rumen contents cannot be identified as the particles are so small. It is only possible to make direct observations of feeding roe deer in a limited number of cases, while observations of tamed individuals limit them to some degree in their free choice of feeding place and are more suitable as a means of drawing up a list of plant species consumed than ascertaining the amount of each species consumed.

A botanical analysis was made of samples of food contents taken from the rumen of 125 roe deer, which number included 47 bucks and 78 does, obtained during the hunting season, which for bucks lasts from 11th May to 30th September, and for does from 1st October to 31st January. The animals differed not only in respect of sex, but also of age. Floe deer were shot over almost the whole of the year. The number of samples taken at given seasons of the year was not, for obvious reasons, identical. Spring (11 May - 21 June) samples were taken from 34 rumens, in summer (22 June -21 August) from 11, in autumn (22 August - 21 November) from 16, and in winter (22 November - 31 January) from 64 .

Samples of food contents from the rumen were taken as soon as possible after the animal had been shot and after the contents had been mixed. One sample formed 0.75 of a litre. The material taken was kept frozen at a temperature of 
$-16{ }^{6} \mathrm{C}$ until required for analysis. After thawing the whole contents of the sample were filtered through two sieves held one under the other, with $2 \mathrm{~mm}$ and $0.6 \mathrm{~mm}$ mesh. Material from the first sieve with $2 \mathrm{~mm}$ mesh was washed in distilled water and segregated while wet, then identified as to species or family. The different plant species or families were next drained separately on filter paper and dried for 24 hours at a temperature of $105^{\circ} \mathrm{C}$, i.e. to constant weight. The residue from the second sieve was not identified, but was drained whole on a filter paper and dried to constant weight. The dry mass weight of the whole sample thus consisted of identified and unidentified parts of plants. Calculation was next made of the percentage by weight of the different species of plants and unidentified particles in the whole of the sample.

Identifications were made on the basis of anatomical features of different plant species of families (Rostafiński \& Seid, 1965; Szafer et al., Brüll, 1976).

Four groups were distinguished among the identified species of plant: (1) cultivated plants, (2) grasses, (3) other plants, (4) trees. By dividing plants in this way it was possible to estimate the importance of different groups, particularly of cultivated plants, in the roe deer's food.

\section{RESULTS}

\subsection{Spring}

The intensive development of wild and cultivated plants at this season of the year is reflected in the roe deer's diet, which consists of 71 species of plants, 59 of which are herb layer plants, and 12 tree species (Table 1). The most important components are lucerne, rye and other grasses, and of the tree species, the young leaves and non-ligneous shoots of willows are most intensively cropped. Among other plant species, a small amount of biomass was found for the following: dandelion, Deschampsia, fescue grass, chickweed and white goosefoot (Table 1).

\subsection{Summer}

The roe deer's food is least diversified during this period, only 9 species of plants being distinguished in the rumen, which was filled with the ears of rye and wheat. Seed lucerne and other grasses were found in small amounts only. Amongst tree species, the leaves and non-ligneous ends of oak shoots were found in 4 rumens (Table 1).

\subsection{Autumn}

In autumn the roe deer's food consists of 26 species of plants, of which tree species form a considerable proportion. During this period, however, they feed chiefly on rye. Potato tubers, leaves and roots of beet, apples, pears and maize grain form a high percentage of their food. The animals readily consume leaves and young shoots of robinia, willow sp. and oak sp. among tree species (Table 1).

7 - Acta Theriologica 


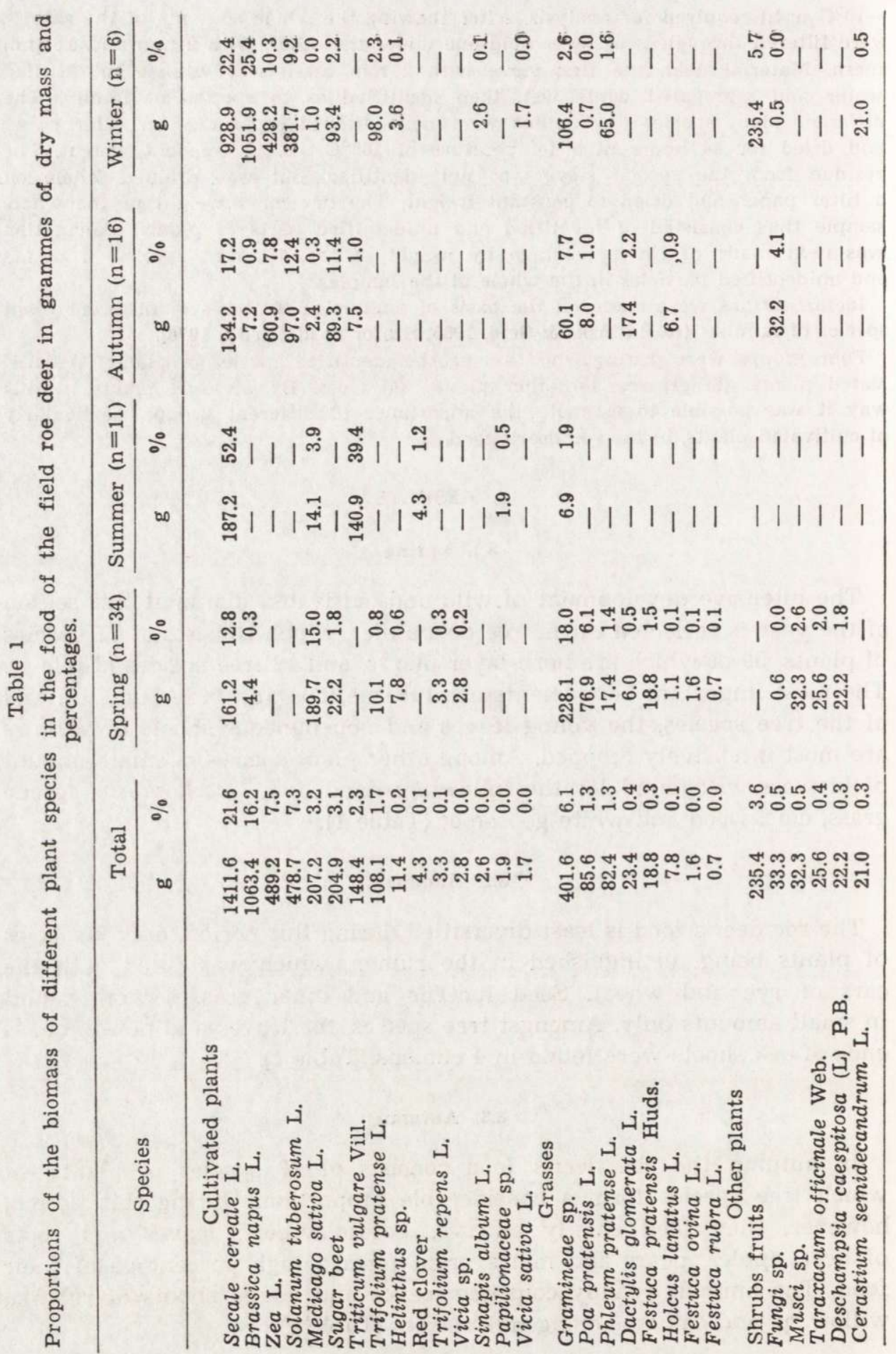




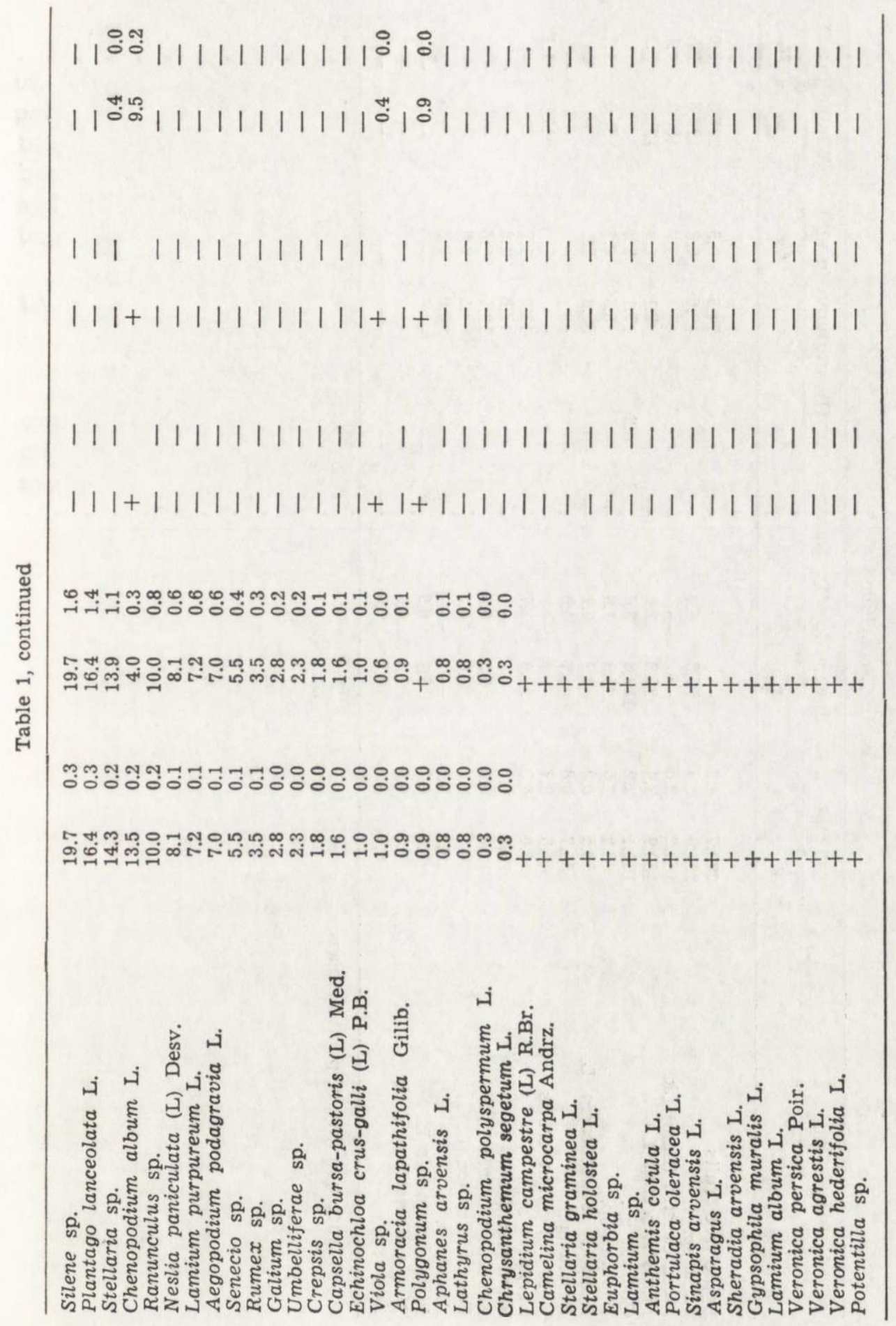




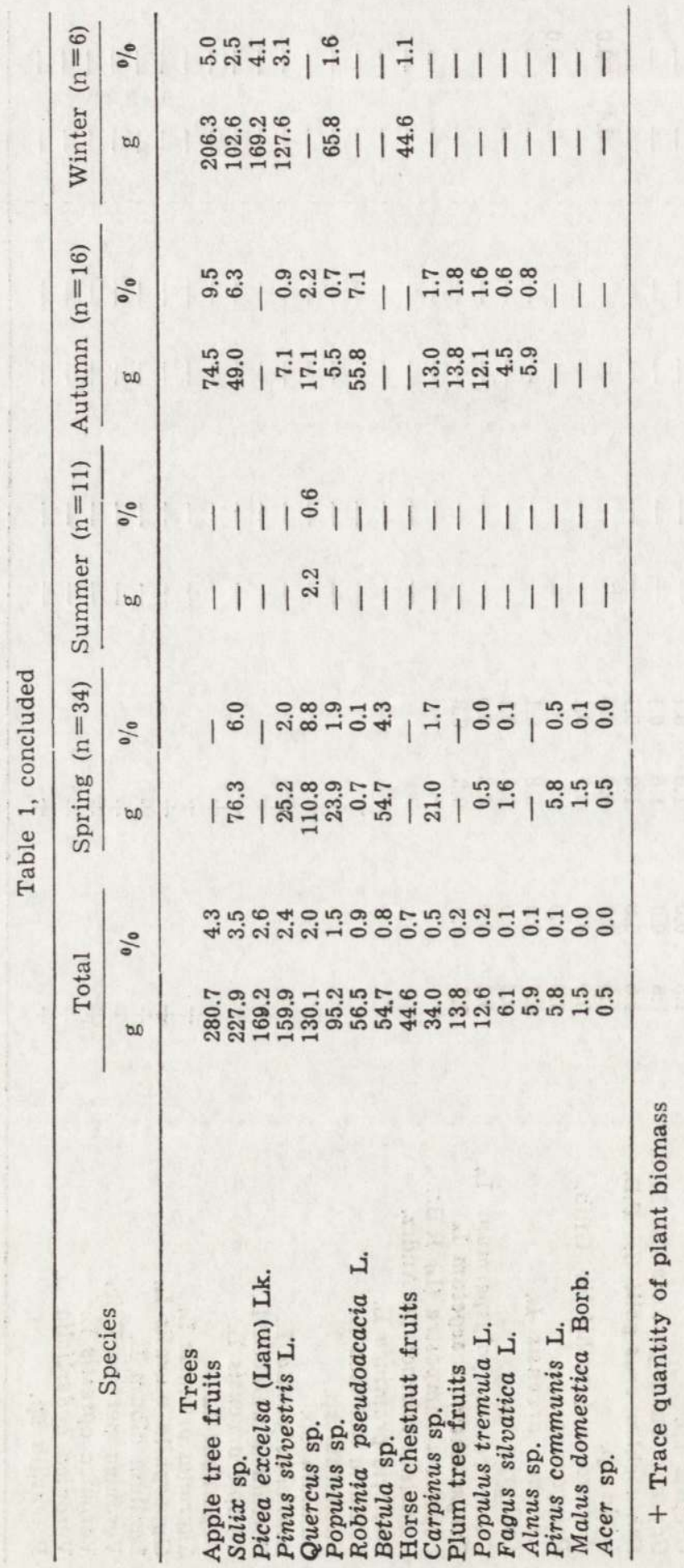




\subsection{Winter}

Twenty-six plant species were distinguished in the roe deer's diet in winter. Rape and rye are of predominant importance during this period, and as in autumn, a considerable percentage is formed by potato tubers, sugar beet leaves and roots, and a small amount of fodder beet, also maize grain and apples. Tree species found include spruce and pine, but the roe deer consumed only the needles of these trees together with the tips of branches (Table 1).

\subsection{Proportion of Different Plant Species in the Roe deer's Food over the Annual}

\section{Cycle}

A total of 85 plant species were found in the food of field roe deer over the yearly cycle, and of this number seed rye is most intensively consumed, forming over $22 \%$ of the food biomass consumed. Rape comes second, but in this case it is intensively consumed by roe deer in winter
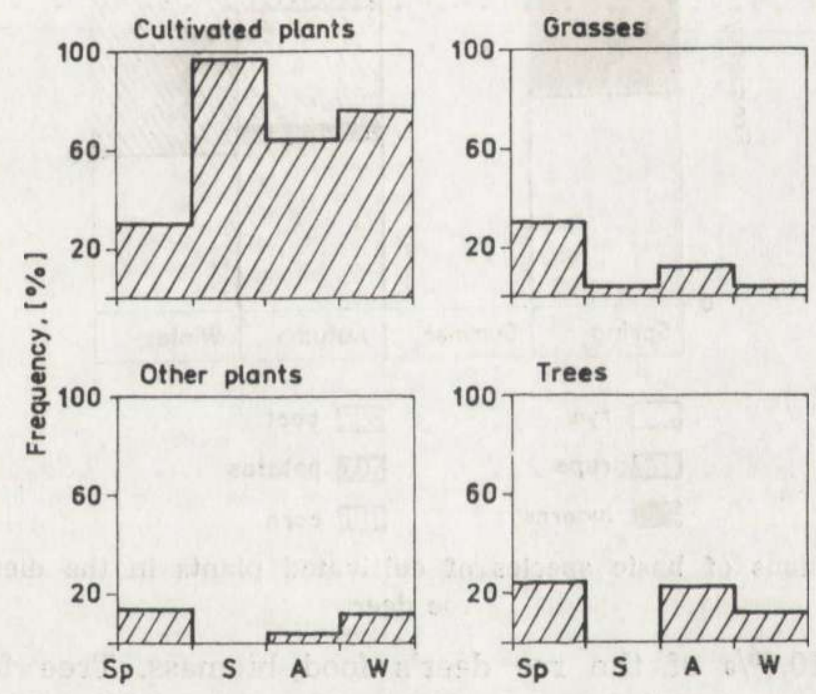

Fig. 1. Proportions of the biomass of different plant groups in the food of the field roe deer. Sp - spring, S - summer, A - autumn, W - winter.

only (Table 1). Among the plants frequently found in rumens, but only in small amounts by weight, are: dandelion, chickweed and white goosefoot. The other plant species are found in small amounts only and in a small number of rumens. Among tree species willow leaves and young shoots are of greatest importance as food for the field roe deer, which feed or other species of trees only from time to time and to a small extent (Table 1). 
Cultivated plants form the basic group of fundamental importance in the field roe deer's diet. On an average over the course of a year their percentage in the food biomass is about $66 \%$, and is highest in summer and winter (Fig. 1). The proportion of different wild grasses is also important $(8.8 \%$ ). Roe deer most readily feed on different kinds of grasses in spring, when they form about $29 \%$ of the biomass of their food. In summer and winter only negligible amounts of grass are consumed. The variety of species included in the composition of the "other plants" group resulted in their being consumed most equally as the roe deer's food at all other times of the year apart from summer. The different degree of development of different species also affects the way in which the animals make use of them. Over the yearly cycle

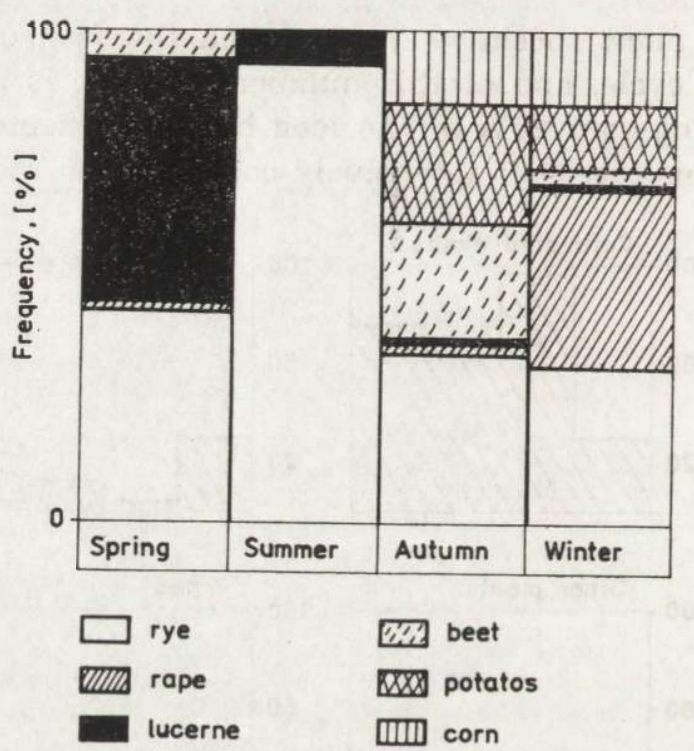

Fig. 2. Proportions of basic species of cultivated plants in the diet of the field roe deer.

they form $10.6 \%$ of the roe deer's food biomass. Tree food is most intensively consumed by roe deer in spring and autumn. The proportion of leaves and young shoots of deciduous trees in the roe deer's diet at these two seasons of the year is considerable and forms over $20 \%$ of food biomass over the yearly cycle. Trees form $14.6 \%$ of the whole of the roe deer's diet. Using the Chi-square test of homogeneity, highly significant confirmation was obtained of the unequal consumption of different plant groups as food by roe deer over the yearly cycle $\chi^{2}=1465.2$, $r=9$ d.f.) (Fig. 1).

Among the species commonly used in agriculture the greatest importance as food for roe deer is exhibited by seed rye (Fig. 2), which is 
consumed by these animals over the whole of the year, while other cultivated plants are consumed only seasonally. An extreme example of this is provided by potato tubers and maize grain. These plants are available to roe deer in autumn and winter, and early spring - in winter and spring only when the animals are able to dig them out from under snow or find them when the snow melts. Each of these kinds of food forms over $10 \%$ of the whole of the animals' food in autumn and winter. Lucerne, however, is accessible to roe deer over the whole year, but is intensively used as food only in spring and early summer. There is therefore a highly significant relation between consumption by roe deer of a given species of cultivated plant and the season of the year $\chi^{2}=4413.3 r=2$ d.f.) (Fig. 2).

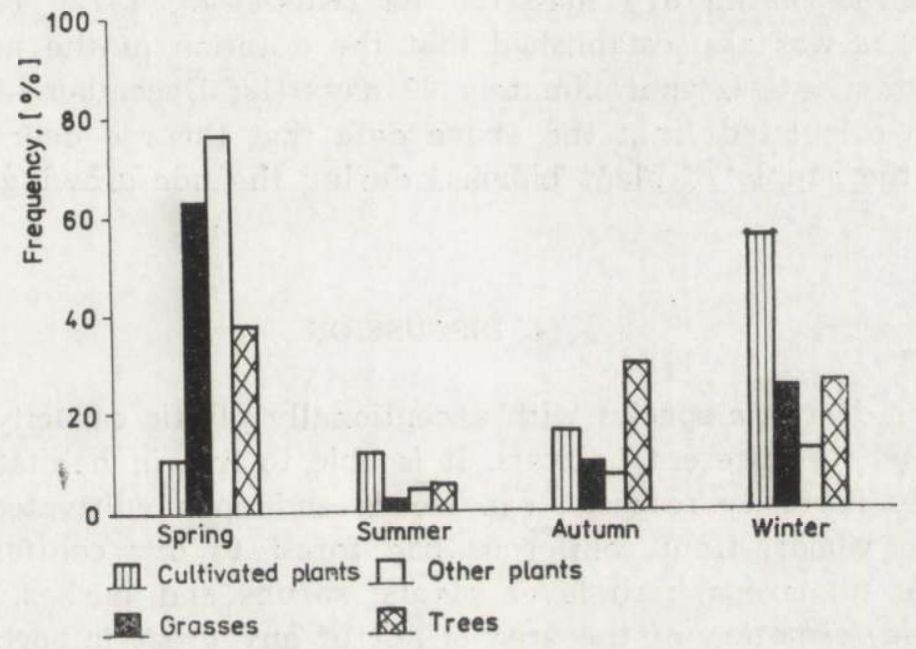

Fig. 3. Frequency of occurrence of four plant groups in the rumen of the field roe deer.

In spring three groups dominate in the roe deer's food: grasses, other plant increases, and in winter predominates in the roe deer's food. In plants increases, and in winter predominates in the roe deer's food. In this case also a highly significant relation was round between frequency of groups of plants in the roe deer's food and the season of the year $\chi^{2}=44.7, r=4$ d.f.) (Fig. 3 ).

Rye and rape form the chief components and the cultivated plant food consumed in winter. The roe deer concentrate in winter herds within cultivated areas occupied by these plants, and also on lucerne fields (Bresiński, 1981). In winter during the non-growing period the biomass of cultivated plants does not increase and roe deer feed inten- 
sively on them, causing a systematic and constant decrease in biomass. This problem must be considered from the viewpoint of possible damage caused by roe deer in plant production, and consequently the effect on cultivated plants of this population in winter was defined on the following bases: (1) mean daily food requirements of roe deer are about $500 \mathrm{~g}$ of dry mass (Kałuziński \& Bresiński, 1976; Perzanowski, 1978; Drożdż, 1979), of which $88.8 \%$ is formed by cultivated plants (Fig. 1)= $=444 \mathrm{~g}$ dry mass, (2) total area of winter cereals, rape and lucerne accessible to roe deer within the experimental area was 4200 ha $(\mathrm{Ka}$ łuziński, 1982b), (3) assuming that the whole population, numbering 1628 individuals (Kałuziński, 1982a) feeds on the above-mentioned area, the average density of animals will be about 39 individuals $/ 100$ ha of these crops, (4) average combined supply of biomass from the above crops is $183,300 \mathrm{~kg}$ dry mass/100 ha (Kukielska, 1972; Truszkowski, 1979), (5) it was also established that the duration of the non-growing season for plants is approximately 90 days (1st December-1st March).

It was calculated from the above data that the roe deer population reduces the supply of plant biomass during the non-growing season by only $1 \%$.

\section{DISCUSSION}

The roe deer is a species with exceptionally plastic capacity for adaptating itself to different habitats. It is able to live in habitats differing extremely in many respects, e.g. woods and open cultivated fields. It occurs in woods, from coniferous bog forest to dry coniferous forest devoid of numerous herb layer plants, shrubs and bushes. From this aspect the formation of the area is not of any great importance, since the roe deer lives in all parts of Polish territory, including the most lowland parts and at times also the higher mountainous parts. It is known that the roe deer is systematically extending the northern boundary of its natural occurrence (Helle, 1980). It is therefore important to know how this species of animal manages to obtain sufficient food in natural habitats in many respects so diametrically opposite. A search was therefore made in relevant literature to obtain information on the roe deer's diet when living under different habitat conditions.

When examining the roe deer's food by means of analyzing rumen contents in the Pisz Forest Siuda et al., (1969) reached the conclusion that the basic food of the roe deer consists of parts of trees and bushes, and includes grasses and herb layer plants during the spring and summer only. In winter food derived from trees and bushes formed $43 \%$ of the food of these animals. In the part of the Białowieża Primeval 
Forest within Soviet territory trees and bushes supply $75 \%$ of the roe deer's food in winter, and herb layer plants and grasses constitute their basic food in spring and summer only (Sablina, 1970).

These results differ considerably from the data obtained by Gębczyńska (1980) on the food of the roe deer living in the Polish part of the Białowieża Primeval Forest. According to this author, leaves, buds and small twigs of trees and bushes form $11-12 \%$ of their food in spring and early summer, and $23 \%$ in autumn and winter. Herb layer plants therefore predominate in the roe deer's food over the yearly cycle.

Kossak (1980) carried out systematic observations of feeding tame roe deer in a mixed coniferous forest, and found that the food they consume depends not only on the season of the year, but also on prevailing atmospheric conditions. In winter, on days when there is no snow cover, the percentage of food cropped by roe deer from trees and bushes was about $16 \%$, but when snow covered the ground the percentage of tree and bush species in their food increased abruptly. It must be added that the roe deer observed were only able to move about within a given area, which prevented them from making a free choice of a feeding place.

The data given above on the roe deer's food in the Białowieża Primeval Forest point to considerable differences in the results obtained. The data given by Sablina (1970) differ from those obtained by Gębczyńska (1980) and Kossak (1980). It is difficult to discover the reason for the differences in the above results, as Sablina (1970) does not state which method she used.

In England also changes in the composition of plant species in the roe deer's diet take place depending on the season of the year (Jackson, 1980). In winter some of the coniferous trees and sallow form the roe deer's main food, whereas at other seasons of the year blackberry and rose bushes, and grasses and herb layer plants, form the main food supply of these animals.

In Central Finland, on the other hand, 30\% of the roe deer's food in winter, since studies were made for this season only, consists, of particles of ligneous plants. The remainder of its food consists of herbs, sedge, lichen from trees and other vegetation which these animals dig from under the snow (Helle, 1980).

In the German Democratic Republic Knorr \& Briedermann (1976) determined the composition of the food of roe deer living in a field habitat. According to these authors cultivated plants formed about $85 \%$ cf these animlas' food, tree species only $4 \%$, while the remainder consisted of other herb layer plants. The proportions given above of 
the different groups of plants in the roe deer's food varied at different seasons of the year.

Results similar to the above were obtained by Jonson \& Padaiga (1975) cited after Stubbe \& Passarge (1979). These authors state that in the forest of Lithuania from 79 to $95 \%$ of the roe deer's food at all seasons of the year consist of grasses and cultivated plants. It is only in the forest of Lithuania from 79 to $95 \%$ of the roe deer's food at all are of great importance in the roe deer' diet.

On the strength of the data from literature presented above and the results of studies given in this paper, it can be said that the roe deer's food varies with the season in all the habitats in which this animal lives. Amongst roe deer inhabiting a forest habitat the proportion of their food formed by parts of trees and bushes is at all seasons of the year, and particularly in winter, higher than in animals occurring on cultivated fields. The significant differences in the diet of roe deer inhabiting different natural habitats is evidence of the very plastic food requirements of this species.

It is clear from studies on the digestion of natural food by roe deer that in order to maintain energy budget balance roe deer must consume plants characterized by a digestion coefficient higher than approx. $60 \%$ (Perzanowski, 1978; Drożdż, 1979). In winter when the digestion coefficient of twig food is about $40 \%$, the nutrition of the roe deer does not depend on this kind of food, but on the possibility of supplementing it by easily digestible food (Drożdż, 1979).

The above studies show that during the critical season for roe deer, that is, winter, these animals cannot find such easily digested food in sufficient amounts in all forest habitats, but the reverse applies to the roe deer's winter supply of food in the cultivated fields. In the light of the foregoing it may be said that from the food aspect cultivated fields form a more favourable habitat for roe deer than forests.

The whole roe deer population living in the experimental area reduces the supply of plant biomass (seed rye, rape and lucerne) by $1 \%$ during the non-growing period of plants. The studies made by Truszkowski (1979) show that when the above plants are deprived of as much as $30 \%$ of their biomass during the vegetation resting period, this does not reduce main crops, consequently in a general way there is no question of a direct unfavourable effect being exerted by feeding roe deer on plant production in agrocenoses. 


\section{REFERENCES}

1. Bobek B., Weiner J. \& Zieliński J., 1972: Food supply and its consumption by deer in a deciduous forest of Southern Poland. Acta theriol., 17, 15: 187-202.

2. Borowski S. \& Kossak S., 1975: The food habits of deer in the Białowieża Primeval Forest. Acta theriol., 20, 32: 463-506.

3. Bresiński W., 1981: Stadowość u sarn polnych (Capreolus capreolus L.) jako wyraz przystosowania do bytowania w warunkach krajobrazu rolniczego. $\mathrm{Ph}$ D Theses, Inst. Appl. Zool., Agric. Acad. Poznań: 1-45.

4. Brüll U., 1976: Nahrungsbiologische Studien am Feldhasen in Schleswig-Holstein. Ein Beitrag zu Asungsverbesserung. [In: "Ecology and management of European hare populations", Eds. Z. Pielowski \& Z. Pucek]. Państw. Wyd. Rol. i Leśne: 93-99. Warszawa.

5. Cederlund G., Ljunggvist H., Markgren G. \& Stalfelt F., 1980: Food of moose and roe-deer at Grimsö in Central Sweden. Results of rumen content analyses. Viltrevy, 11, 4: 169-247.

6. Drożdż A., 1979: Seasonal intake and digestibility of natural foods by roe-deer. Acta theriol., 24, 13: 137-170.

7. Dzięciołowski R., 1971: Sytuacja troficzna populacji jeleni w zależności od warunków środowiskowych. Pr. Inst. Bad. Leśnictwa, 403: 1-43.

8. Fruziński B., Łabudzki L. \& Wlazełko M., 1978: Próba oceny ekonomicznej szkód powstałych na skutek spałowania drzewostanów liściastych Puszczy Bialowieskiej. Roczn. Akad. Roln. Poznań, 104: 15-23.

9. Gębszyńska Z., 1980: Food of the roe deer and red deer in the Białowieża Primeval Forest. Acta theriol., 25: 487-500.

10. Helle P., 1980: Food composition and feeding habits of the roe deer in winter in Central Finland. Acta theriol., 25: 395-402.

11. Jackson J., 1980: The annual diet of the roe-deer (Capreolus capreolus) in the New Forest, Hampshire, as determined by rumen content analysis. J. Zool., 192: 71-83. Londyn.

12. Kałuziński J., 1974: The occurrence and distribution of field ecotype of roe deer in Poland. Acta theriol., 19: 291-300.

13. Kałuziński J. \& Bresiński W., 1976: The effect of the European hare and roe deer populations on the yields of cultivated plants. [In: "Ecology and management of European hare populations", Eds. Z. Pielowski \& Z. Pucek]. Państw. Wyd. Roln. i Leśne: 247-253. Warszawa.

14. Kałuziński J. \& Pielowski Z., 1976: The effect of technical agricultural operations on the hare population. [In: "Ecology and management of European hare populations", Eds. Z. Pielowski \& Z. Pucek]. Państw. Wyd. Roln. i Leśne: 205211. Warszawa.

15. Kałuziński J., 1982a: Dynamics and structure of a field roe deer population. Acta theriol., 27: $385-408$.

16. Kałuziński J., 1982b: Roe deer mortality due to mechanization of work in agrocenoses. Acta theriol., 27: 449-455.

17. Knorr H. \& Briedermann L., 1976: Die Ernährung des Feldrehes. Jadg-informationen, 1: 40-51.

18. Kossak S., 1980: Badania nad sytuacją troficzną sarn na siedlisku boru mieszanego w Puszczy Białowieskiej. Ph. D. Theses, Forest Research Inst. Warszawa: 1-111.

19. Kukielska C., 1972: Produkcja pierwotna pól uprawnych. Zesz. Nauk. I.E. PAN, 5: 165-168. 
20. Perzanowski K., 1978: The effect of winter food composition on roe-deer energy budget. Acta theriol., 23, 31: 456-467.

21. Pielowski Z., 1975: Charakterystyka ekologiczna populacji zająca (Lepus europaeus Pallas, 1778). Roczn. Akad. Roln. Poznań, Pr. habil.: 1-33.

22. Rostafiński J. \& Seid O., 1965: Przewodnik do oznaczania roślin. Państw. Wyd. Rol. i Leśne: 1-444. Warszawa.

23. Sablina T. B., 1970: Evolucija piščevaritelnoj sistemy oleniej. Izd. Nauka: 1-247. Moskva.

24. Siuda A., Zurowski W. \& Siuda H., 1969: The food of the roe-deer. Acta theriol., 14, 18: $247-262$.

25. Stubbe Ch. \& Passarge H., 1979: Rehwild. VEB Deutscher Landwirtschaftsverlag: 1-432. Berlin.

26. Szafer W., Kulczyński H. V Pawłowski B., 1967: Rośliny polskie. Państw. Wyd. Naukowe: 1-1020. Warszawa.

27. Szmidt A., 1975: Food preference of roe-deer in relation to principal species of forest trees and shrubs. Acta theriol., 20, 20: 255-266.

28. Truszkowski J., 1979: Wpływ nornika polnego (Microtus arvalic Pallas, 1779) na roślinność agroekosystemów. Ph. D. Theses, Inst. of Agric. Biol., Poznań: 1-52.

Accepted, February 10, 1982.

Jan KAŁUZIŃSKI

\section{SKŁAD POKARMU SARN BYTUJACYCH NA POLACH}

I WPEYW ICH ŻEROWANIA NA PRODUKCJE ROSLINNA

\section{Streszczenie}

Celem pracy jest poznanie składu żeru sarn, zasiedlających środowisko pól uprawnych oraz określenie użytkowania zasobów pokarmowych przez populację tych zwierząt.

Treść pokarmową do analizy uzyskano ze żwaczy sarn pozyskanych na terenie doświadczalnym (o pow. 13,5 tys. ha) Stacji Badawczej Polskiego Związku Łowieckiego w Czempiniu. Teren ten licznie zasiedlony jest przez populacje sarn polnych. Łącznie poddano analizie 125 żwaczy. Ustalono, że żer sarn polnych składa się z 85 gatunków roślin (Tabela 1). Zasadnicze znaczenie w pokarmie tych zwierząt stanowią rośliny uprawne. Srednio w ciągu roku udział ich w biomasie pokarmu wynoci ca $66 \%$, a największy jest latem i zimą $97 \%$; $74 \%$ (Rys. 1). Znaczący jest także udzial traw odpowiednio - ca $8,8 \%$. Sarny najchętniej żerują na tych roślinach w okresie wiosny. Stanowią one wtedy ca $29 \%$ biomasy ich pokarmu. Części roślin drzewiastych a więc liście i młode pędy oraz, w okresie zimy, igły drzew szpilkowych reprezentowane są w $14,6 \%$ w diecie sarn. Wszystkie inne gatunki roślin (poza drzewiastymi) łącznie stanowią $85,4 \%$ całkowitego żeru sarn polnych.

Spośród gatunków powszechnie rolniczo uprawianych najważniejsze znaczenie jako żer sarn ma żyto siewne (Ryc. 2). Stanowi ono średnio rocznie ponad $22 \%$ pokarmu tych zwierząt.

$\mathrm{Na}$ podstawie uzyskanych w pracy wyników i innych danych wyliczono, że cala populacja sarn w okresie spoczynku wegetacyjnego uszezupla zapas biomasy roślin (żyta siewnego, rzepaku i lucerny) o $1 \%$. Wynik ten $\mathrm{i}$ inne dane literaturowe pozwalają stwierdzić, że bytujące na polach sarny nie mają bezpośredniego (poprzez żerowanie) negatywnego wplywu na produkcję powszechnie uprawianych roślin. 